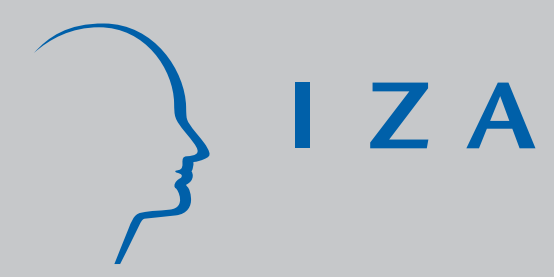

IZADP No. 1017

Estimating the Returns to Community College Schooling for Displaced Workers

Louis J acobson

Robert LaLonde

Daniel G. Sullivan

February 2004 


\title{
Estimating the Returns to Community College Schooling for Displaced Workers
}

\author{
Louis Jacobson \\ Westat Inc.
}

Robert LaLonde

University of Chicago, NBER

and IZA Bonn

\section{Daniel G. Sullivan}

Federal Reserve Bank of Chicago

\author{
Discussion Paper No. 1017 \\ February 2004
}

\author{
IZA \\ P.O. Box 7240 \\ 53072 Bonn \\ Germany \\ Phone: +49-228-3894-0 \\ Fax: +49-228-3894-180 \\ Email: iza@iza.org
}

\begin{abstract}
Any opinions expressed here are those of the author(s) and not those of the institute. Research disseminated by IZA may include views on policy, but the institute itself takes no institutional policy positions.

The Institute for the Study of Labor (IZA) in Bonn is a local and virtual international research center and a place of communication between science, politics and business. IZA is an independent nonprofit company supported by Deutsche Post World Net. The center is associated with the University of Bonn and offers a stimulating research environment through its research networks, research support, and visitors and doctoral programs. IZA engages in (i) original and internationally competitive research in all fields of labor economics, (ii) development of policy concepts, and (iii) dissemination of research results and concepts to the interested public.
\end{abstract}

IZA Discussion Papers often represent preliminary work and are circulated to encourage discussion. Citation of such a paper should account for its provisional character. A revised version may be available on the IZA website (www.iza.org) or directly from the author. 


\section{ABSTRACT}

\section{Estimating the Returns to Community College Schooling for Displaced Workers*}

Studies show that high-tenure displaced workers typically incur substantial long-term earnings losses. As these losses have become increasingly apparent, policy makers have significantly expanded resources for retraining, much of which takes place in regular community college classes. To analyze the effectiveness of such training, we link administrative earnings records with the community college transcript records of workers displaced from jobs during the first half of the 1990s in Washington State. We explore several issues of statistical specification for regression models quantifying the impact of community college credits on earnings. These include (i) how to allow for a transition period immediately after the end of workers' schooling when their earnings may be temporarily depressed, (ii) whether earnings gains are strictly proportional to credits earned, and (iii) how to model worker-specific unobserved heterogeneity. In our preferred specification, we find that the equivalent of an academic year of community college schooling raises the long-term earnings of displaced workers by an average of about 9 percent for men and about 13 percent for women. However, these average returns mask substantial variation in the returns associated with different types of courses. On the one hand, we estimate that an academic year of more technically oriented vocational and academic math and science courses raise earnings by about 14 percent for men and 29 percent for women. On the other hand, we estimate that less technically oriented courses yield very low and possibly zero returns. About one third of the increase in earnings associated with more technically oriented vocational and academic math and science courses is estimated to be due to increases in wage rates, with the remainder attributable to increased hours of work.

JEL Classification: J31

Keywords: $\quad$ unemployment, training, schooling, evaluation

Corresponding author:

Robert J. LaLonde

Irving B. Harris Graduate School of Public Policy Studies

The University of Chicago

1155 East 60th Street

Chicago, IL 60637

USA

Email: r-lalonde@uchicago.edu

\footnotetext{
* The authors thank Jeff Jaksich and the Washington State Training and Education Coordinating Board for providing the data for this project. We have benefited from comments by John Ham, James Heckman, Guido Imbens, Alona Lerman, Kevin Hollenbeck and participants at the HSFR Conference on Unemployment and Labor Market Policy, in Sweden, and workshops at Chicago, Harvard, Princeton, Northwestern, Michigan, Michigan State, the National Bureau of Economic Research, UCLA, Maryland, Syracuse, Bureau of Labor Statistics, the Upjohn Institute for Employment Research, CIDE, and the Federal Reserve Bank of Chicago. Ken Housinger, Jim Sullivan, and Abigail Waggoner provided technical assistance. Some of this research was funded under U.S. Department of Labor ETA contract 99-0-0584-75-055-01 and by the Washington State Workforce Training and Education Coordinating Board. The views expressed in this paper are solely those of the authors and do not necessarily represent the views of the state of Washington, the U.S. Department of Labor, the Federal Reserve Bank of Chicago or the Federal Reserve System.
} 


\section{Introduction}

Layoffs of experienced workers are an enduring aspect of U.S. labor markets (Farber, 1993, 1997; Aaronson and Sullivan, 1998; Helwig, 2001). Studies using longitudinal data indicate that affected workers tend to incur substantial long-term earnings losses long after they return to work (Ruhm, 1991; Jacobson, LaLonde, and Sullivan, 1993a, 1993b, 1993c; Fallick, 1996; Kletzer 1998). Given this prospect of significantly lower earnings, it is natural for displaced workers to consider returning to school to obtain new skills that would allow them to find better jobs. Indeed, policy makers often propose subsidizing retraining as a way to cushion the blow associated with job displacement. As the costs of worker displacement became more apparent in the 1990s, and the incidence of displacement became more wide spread among industrial sectors, policy makers substantially expanded expenditures on employment and training services for displaced workers, even as they scaled back expenditures on similar services for youths (LaLonde 2002). Much of this training takes place in regular courses taught in the nation's community colleges.

Policy makers' heightened support for worker retraining has occurred even though there is relatively little evidence on its likely impacts. The many studies of public sector-sponsored training for economically disadvantaged persons are not directly relevant because most displaced workers have substantial work experience and thus are likely to be more employable without retraining than the workers in those studies. Neither does the voluminous literature on the returns to schooling necessarily apply because displaced workers usually have been out of school for many years, often take only very few courses, tend to be work longer hours for pay while attending school, and are usually much older than the typical student. Such factors may make it more difficult to learn new skills.

Much of the knowledge we do have of the effects of training displaced workers comes from several demonstration programs implemented during the 1980s (Bloom, 1990; Leigh, 1990). A more recent study examines the impact of training on a relatively small subset of displaced workers who lost their jobs as a result of increased import competition (Corson, Decker, Gleason, and Nicholson, 1993). These studies indicate that displaced workers benefit from job search assistance; that access to classroom vocational instruction or on-the-job training usually has little effect on subsequent earnings; and that female displaced workers likely benefit more from employment and training services than do their male counterparts (LaLonde, 1995).

This paper presents new evidence on the benefits of retraining prime-aged adults by analyzing the impacts of community college schooling on displaced workers' earnings in Washington State during the 1990s. We focus on this group of workers because of the ability to construct a large longi- 
tudinal database well suited to the study of training impacts. We constructed this database by merging administrative earnings and unemployment insurance records with community college transcript records. The administrative earnings records cover substantial periods of time both before workers' displacements and after their schooling, while the transcript records provide unusually detailed information about the type, intensity, and duration of classroom training.

We explore several issues in the specification of longitudinal regression models that quantify the impacts of community college credits on earnings and other labor market outcomes. First, because it apparently takes time to realize the full benefits of training, we find that it is important to allow for the possibility that workers' earnings may be temporarily depressed in the period immediately after they leave community college. Accounting for such a transition substantially increases estimates of long-term earnings gains.

Second, we find that it is important to allow for departures from strict proportionality between earnings increases and credits earned, an assumption that has been imposed, for example, by Kane and Rouse (1995) in a study of the returns to community college. Indeed, in some specifications that relax proportionality, earning even a single credit is estimated to significantly increase expectations of subsequent earnings. The earnings increase associated with this first credit is many times greater than that associated with additional credits. It also is probably higher than can be plausibly attributed to factors such as access to wider networks for job search that may be provided by the community college environment. We conjecture that the higher earnings associated with merely "showing up" at community college are due mainly to the effects of nonrandom selection into training. Thus we focus our attention on the per-credit earnings increases associated with completing additional credits. Allowing for nonproportional effects of credits on earnings in some cases substantially lowers the estimated impact of community college training.

Finally, because we have longitudinal data, we can estimate the gains from schooling in models that allow for forms of unobserved heterogeneity that may be correlated with training decisions. We find that the standard fixed-effect specification, which has been employed to estimate the returns to schooling by Angrist and Newey (1991), is inadequate for our purposes because workers who earn many credits, especially many credits in nontechnical subjects, tend to have more slowly growing earnings in the period before training than one would expect given their observable characteristics. Thus, we also estimate models that include worker-specific time trends in addition to fixed effects. These models effectively control for any unobserved worker characteristics that are changing at a constant rate over time. Allowing for this richer form of worker-specific heterogeneity raises estimates of the effects of training, especially the effects of nontechnical training. 
In our preferred specification, which allows for (i) post-schooling transition effects, (ii) deviations from strict proportionality, and (iii) individual-specific time trends, we find that the equivalent of a year of community college schooling increases displaced workers' earnings by about 9 percent for men and 13 percent for women. ${ }^{1}$ These gains from schooling compare favorably to those reported for younger persons in the returns to schooling literature. We also find that returns differ substantially by type of course. Credits completed in courses teaching quantitative or more technically oriented vocational subject matter generate earnings gains that average 14 percent for men and 29 percent for women. By contrast, courses teaching non-quantitative or non-technical vocational skills are associated with small or possibly zero earnings gains.

The remainder of the paper proceeds as follows: Section II provides institutional background on public sector-sponsored retraining programs for displaced workers and describes the data. Section III presents our econometric model for estimating the effects of community college schooling. In section IV, we present our estimates and some concluding remarks follow in Section V.

\section{Training for Displaced Workers}

\section{The Role of Community Colleges}

Community colleges have played an increasingly prominent role in worker retraining policy during the last 30 years. This change coincides with the greater emphasis that these institutions have given to vocational training. Although community colleges continue to offer academically inclined students traditional college-level courses, they now also offer vocationally oriented courses that in the past were offered mainly by proprietary schools and vocational institutes (Freeman, 1974; Grubb, 1993; Kane and Rouse, 1999.) Typical course offerings cover areas as diverse as computer information systems, food preparation and management, real estate, word processing, respiratory therapy, the construction trades, and automobile repair. Moreover, students who complete these kinds of courses can often obtain certification in a particular trade or take state licensing exams.

Given the existence of these vocational programs, community colleges are natural providers of public sector-sponsored retraining. Indeed, several federal programs have provided funding to support displaced workers' community college attendance. These programs include those funded

1. Relatively few displaced workers attend as much as an academic year of community college. Nevertheless, computing estimates corresponding to this hypothetical level provides a convenient benchmark to compare our results to standard estimates from the returns to schooling literature. 
under the Trade Adjustment Assistance Act (TAA), the 1972 Higher Education Amendments (Pell Grants), and Title I of the Workforce Investment Act (WIA), which in 1998 replaced the Economically Displaced Worker Adjustment Act (EDWAA).

Today, most displaced workers who receive subsidized retraining participate in programs authorized under WIA. To provide for these training services, the federal government allocates funds to state and local authorities. They, in turn, provide displaced workers with Individual Training Accounts, which workers can use to obtain training from certified providers. In practice these funds are frequently spent on regular two-year community colleges courses. In these mainstream

programs, displaced workers take classes with non-displaced workers and full-time students. ${ }^{2}$ It is the impact of these regular community college courses on displaced workers' earnings that we study in this paper.

\section{Data Sources}

We analyze the earnings histories of approximately 97,000 workers who had three or more years of job tenure when they were permanently laid off from their jobs between 1990 and 1994 in Washington State and who remained attached to the state's labor force from 1987 through 1995. About 16,000 of the workers in our sample earned some community college credits by 1996 . We excluded "low-tenure" displaced workers, because public policy has been most concerned about the long-term consequences of the job losses of experienced workers. We exclude workers with low labor market attachment because for such workers it is difficult to distinguish between true unemployment and other reasons why administrative data show no earnings. The latter include the possibilities that workers have moved out of state, that they are working in the uncovered or illegal sectors, and that they are working under an incorrect social security number.

The administrative records of the state's unemployment insurance system provide information on individuals' quarterly earnings and hours worked from 1987 to 1995, their birth year, race and sex, their quarter of separation, job tenure and level of education at separation, and, for each calendar year, their primary employer's 4-digit SIC code, geographic location, and number of employees. Community college records provide information on students' demographic characteristics, listings of the credit and noncredit courses in which they enrolled, and the grades that they received in courses taken for credit. Together they provide a rich data base for assessing the effects of retraining on displaced workers' earnings. The Appendix provides further details about

2. About one-third of community college students in the United States are over 30, and the vast majority work at least part-time (Kane and Rouse, 1999). 
the construction of the sample.

\section{Characteristics of Displaced Workers}

Like much of the nation, Washington State's economy worsened in 1990. The unemployment rate rose, with several sectors especially hard hit, including the aerospace and wood products industries. In response, the state legislature established a program in 1993 that provided community colleges with additional funding if they enrolled displaced workers in their programs. But because the substantial increase in federal subsidies for retraining displaced workers had not yet taken place, most of the state's unemployed workers attended community college at their own expense. Thus, the workers that we study should be reasonably typical of those displaced in a relatively weak labor market and who decide on their own to return to school for more training.

Displaced workers who enroll in community college classes are typically prime-aged adults, many of who have attended college before, and who have been displaced from jobs from a wide array of industries. As shown by Panel A of Table 1, the average age of displaced workers in the

Washington State who enrolled and completed community college courses was approximately 36 for males and 37 for females. Approximately one-half of both the male and female community college participants had previously attended college at some point during their lives. The table also indicates that a substantial fraction of both males and females were displaced from outside the durable goods industries (c.f., Farber, 1997; Aaronson and Sullivan, 1998; Helwig, 2001). Indeed, approximately 70 percent of the female displaced workers lost jobs held in the non-goods producing sector of the economy.

Community college participants differ in some important ways from other displaced workers in the sample. As shown by Panel A of Table 1, participants tend to be younger, have slightly less prior job tenure, and are more likely to be female. They also are slightly more likely to be located in one the state's rural counties. Most striking, however, is that those displaced workers who completed community college courses are substantially more likely to have previously attended college than their counterparts who never completed any community college courses following their job losses.

As shown by Panel B of Table 1, participants completed on average about 30 credits. In Washington State community colleges, a full-time academic year consists of 45 credits. Thus community college participants who earned at least one credit typically completed about two-thirds of a year of schooling. Panel B of Table 1 also shows the breakdown of credits into two broad categories. "Group 1" courses include academic courses in math and science as well as courses related to the 
health professions, technical trades (e.g. air conditioner repair), and technical professions (e.g., software development). "Group 2" consist of all other courses and includes academic social sciences and humanities courses as well as courses in business, sales and less technical vocational tracts, personal health, physical education, consumer education, basic skills, and English as a second language courses. ${ }^{3}$ Approximately one-third of the credits completed by female displaced workers were in courses teaching the more technically oriented academic or vocational skills. Male displaced workers completed more than one-half of their credits in these Group 1 courses. This difference between the content of courses completed by males and females suggests that community college schooling may have different impacts for men and women.

Figure 1 plots mean earnings over time for workers displaced in 1991 who earned community college credits and a comparison group composed of those who did not. Among those who earned credits, we distinguish between those who earned more Group 1 credits and those who earned more Group 2 credits. Consistent with the evidence in Jacobson, LaLonde, and Sullivan (1993a), Figure 1 shows that displaced workers' real quarterly earnings (1995 dollars) declined during the two-year period prior to their displacements. Moreover, their earnings fell sharply after their displacements. Further, displaced workers' quarterly earnings remain roughly $\$ 2,000$ below their peak pre-displacement levels even after four years. In addition, we observe that while the earnings of Group 1 participants are similar to the comparisons, the earnings of the Group 2 participants are consistently lower than the earnings of the other groups, both prior to and after their job losses.

Though informative about the general characteristics of the data, simple comparisons between earnings of the groups shown in Figure 1, do not necessarily indicate the effectiveness of community college schooling. For instance, although Group 1 concentrators seem to have lost ground relative to nonparticipants, this does not necessarily mean that training was ineffective. These participants differ from the nonparticipants in gender, race, age, prior education, and the industries from which they were displaced, factors which may have an impact on their subsequent earnings. The statistical model we have developed and the empirical work presented below account for such possibilities.

\section{The Econometric Model}

We take three different approaches to parameterizing the impact of community college participa-

3. Table A1 shows the categories of courses included in the two groups of courses. 
tion on earnings. The first two approaches have been widely implemented in the program evaluation and returns to schooling literature. Our third approach is a hybrid of the first two that we believe does a more credible job accounting for selection and focuses on the variation in training that is most likely to give an unbiased estimate of the impact of community college schooling.

In our first approach, we treat participation as a single discrete or "binary" event, as in much of the literature on "program evaluation" (Ashenfelter, 1978; Ashenfelter and Card, 1985; Heckman, LaLonde, and Smith, 1999). This approach compares regression-adjusted post-program earnings of workers who did and did not complete community college schooling. In our regression analysis, we account for unobserved characteristics that are either fixed or changing at a constant rate over time by exploiting information on individuals' earnings over several years prior to their schooling.

In our second approach, we assume the effects of community college are proportional to the number of credits earned. Unlike the first approach, this approach identifies the effects of training both from differences in the earnings growth of participants and non-participants and from differences in earnings growth of displaced workers who obtain differing numbers of credits. Thus, in a sense, the "trainees" serve as their own comparison group. Indeed, given the assumption that earnings gains are proportional to credits, the effects of training could, in principle, be estimated without using any data on non-participants. In practice, of course, there would still be important efficiency gains from including data on displaced workers who did not attend community college.

Our second approach is analogous to specifications employed in the "returns-to-schooling" literure. Where that literature measures the return to a year of schooling, our approach measures the impact of a community college credit. This is of value because the policy choice is not simply whether displaced workers should attend community college, but also how long and how intensively they should attend. In the literature on the returns to community college schooling, this approach has been employed by Kane and Rouse (1995).

Our third approach is a hybrid of the first two approaches. We allow for an impact of community college that is proportional to credits as in the "returns to schooling" approach and, in addition, for a discrete effect of training participation, as in the program-evaluation approach. There are two advantages of this third approach. First, there may be effects of community college attendance that are not proportional to the number of credits earned. For instance, attending community college may provide "networking" opportunities that facilitate job search. Much of such benefits are likely to be felt soon after students start school. Thus, allowing for a discrete effect of having enrolled in school, which does not depend on credits earned, may identify such effects. 
A second advantage of our hybrid approach is that displaced workers who do and do not participate in training may differ in some time-varying manner that is not fully accounted for by regression adjustment. In such cases, estimates of the impact of credits employing the pure "returns-toschooling" approach are likely to be biased. However, if given their decisions to attend community college, workers acquiring different numbers of credits differ systematically only in respects fully accounted for by regression adjustment, the resulting estimates of the per-credit effect in the hybrid approach will be unbiased. In previous work (Jacobson, LaLonde, and Sullivan, 1999, 2002), we have found that among those earning a positive number of credits, the relationships between the number of credits earned and various observable variables are significantly weaker than the corresponding relationships between these variables and whether a displaced worker participates in community college schooling. It seems reasonable that a similar pattern should hold for unobservable variables. Thus, we believe estimates of the impact of a community college credit obtained from the hybrid model to be more reliable than estimates obtained by assuming strict proportionality between credits and schooling outcomes.

To implement our three approaches for estimating the impact of community college training on workers' earnings, we estimated several linear regression models of the form,

$$
y_{i t}=\alpha_{i}+\omega_{i} t+\gamma_{t}+x_{i t} \beta+\delta_{i t}\left(s_{i}, z_{i}\right)+\tau_{i t}\left(c_{i}, f_{i}, l_{i}, z_{i}\right)+\varepsilon_{i t} .
$$

According to model (1), workers' quarterly earnings, $y_{i t}$, depend on (a) unobserved worker-specific fixed effects and time trends as well as quarter-specific fixed-effects, $\alpha_{i}+\omega_{i} t+\gamma_{t}$; (b) observed time-varying demographic characteristics, $x_{i t} \beta$; (c) the effects of their displacement, $\delta_{i t}\left(s_{i}, z_{i}\right)$, which may depend on the date of their job loss, $s_{i}$, and worker characteristics, $z_{i} ;$ (d) the effects of training, $\tau_{i t}\left(c_{i}, f_{i}, l_{i}, z_{i}\right)$, which may depend on the workers' characteristics as well as the number of credits earned, $c_{i}$, and the first and last quarters of community college attendance, $f_{i}$ and $l_{i}$; and (e) time varying unobserved characteristics, $\varepsilon_{i t}$. We discuss the detailed specification of factors (a) to (d) below.

\section{Controls for worker and time period heterogeneity}

In all of our models, we include time fixed-effects and worker-specific fixed effects. The former controls for forces that effect earnings for all workers equally in a time period. The latter controls for any characteristic that is fixed over time for an individual worker. In addition, in some models we include worker-specific time trends. These controls account for individual-specific heteroge- 
neity that change at a constant rate over time. Previous program evaluations indicate that models with such controls may be more likely to yield unbiased estimates of the impact of training (Bloom, 1984; Ashenfelter and Card, 1985; Heckman and Hotz, 1989).

\section{Observed time-varying demographic characteristics}

In each of our statistical models, we include separate second order polynomials in age for each of the four combinations of sex and minority status. It is important to adjust for age, gender and minority status, because community college participants are typically younger, are disproportionately female and differ from the norm in terms of race, all factors that are associated with differences in earnings growth independent of any effects of schooling.

\section{Effects of displacement}

Previous research has documented the temporal pattern of the impact of displacement on workers' earnings (e.g., Jacobson, LaLonde, and Sullivan, 1993). Displaced workers' earnings typically tend to decline during the period prior to displacement; drop sharply following the quarter of their job loss; and then rise relatively rapidly during the next few quarters before beginning to increase at a slower rate in subsequent periods. Figure 1 indicates that this pattern holds in the Washington State sample analyzed in this paper.

To capture the baseline pattern of displacement effects, we introduce dummy variables for the number of quarters a worker in a particular time period is relative to displacement. Specifically, we assume that the effect of displacement on the earnings of a worker in quarter $t$ who is displaced in quarter $s_{i}$ is a parameter $\delta_{t-s_{i}}$ if $t \geq s_{i}-8$ and is zero otherwise. ${ }^{4}$ Thus the baseline displacement effect can be written as $\delta_{i t}\left(s_{i}, z_{i}\right)=\sum_{k \geq-8} D_{i t}^{k} \delta_{k}$, where $D_{i t}^{k}$ is an indictor variable equal to one when $t-s_{i}=k$ and zero otherwise.

The temporal pattern of displacement effects may differ from the baseline according to such factors as a workers' sex, age, race, location, and previous industry and job tenure. Since whether and to what extent a worker seeks retraining also may depend on these characteristics, it is important to control for differences in the associated displacement effects. We do this by introducing additional interactions between such characteristics and a set of five factors that capture different

4. In preliminary work, we found that displacement effects were very limited prior to two years before separation. 
aspects of the temporal pattern of displacement effects. Specifically, we define,

$$
\begin{aligned}
& F_{i t}^{1}=t-s_{i}+8 \text { if } s_{i}-8 \leq t<s_{i} \text { and } F_{i t}^{1}=0 \text { otherwise, } \\
& F_{i t}^{2}=1 \text { if } t=s_{i} \text { and } F_{i t}^{2}=0 \text { otherwise, } \\
& F_{i t}^{3}=1 \text { if } t>s_{i} \text { and } F_{i t}^{3}=0 \text { otherwise, } \\
& F_{i t}^{4}=t-s_{i} \text { if } t>s_{i} \text { and } F_{i t}^{4}=0 \text { otherwise, and } \\
& F_{i t}^{5}=\left(t-s_{i}\right)^{2} \text { if } t>s_{i} \text { and } F_{i t}^{5}=0 \text { otherwise. }
\end{aligned}
$$

Workers are assumed to differ in their "loadings" on these factors in a manner that is linear in their characteristics, $z_{i}$. Thus, the full displacement effect in our statistical model becomes:

$$
\delta_{i t}\left(s_{i}, z_{i}\right)=\sum_{k \geq-8} D_{i t}^{k} \delta_{k}+\sum_{j=1}^{5} F_{i t}^{j} z_{i} \phi_{j}
$$

where the $\phi_{j}$ are additional parameter vectors to be estimated. Variation in the loading, $z_{i} \phi_{1}$, on the first factor allows for variation in the rate at which earnings dip in the period before displacement. Similarly, variation in the loading, $z_{i} \phi_{2}$, on the second factor allows for the earnings of workers with certain characteristics to drop more sharply in the quarter of their jobs loss. Finally, variation in the loadings, $z_{i} \phi_{3}, z_{i} \phi_{4}$, and $z_{i} \phi_{5}$, the third through the fifth factors, allow for a quadratic departure of workers' earnings from the baseline pattern of displacement effects during the period after displacement.

In our empirical work, the vector of characteristics, $z_{i}$, consists of indicator variables for gender, minority status, four levels of previous education, three regions, for having a previous job in aerospace, a previous job in another manufacturing industry, a previous job in other parts of the goodproducing sector, previous job tenure of less than six years, and age at job loss in the 20s, 30s, $40 \mathrm{~s}$, or 50s. Altogether, our specification of the effects of displacement on earnings is quite flexible, containing approximately 150 parameters. 


\section{Effects of community college attendance}

We allow the form of the "schooling effect," $\tau_{i t}\left(c_{i}, f_{i}, l_{i}, z_{i}\right)$, to depend on whether the worker is in school or finished with classes. In the former case, we expect that schooling may lead to some foregone earnings and specify the impact of schooling on earnings as

$$
\tau_{i t}\left(c_{i}, f_{i}, l_{i}, z_{i}\right)=\psi_{0}+\frac{c_{i}}{\left(l_{i}-f_{i}+1\right)} \psi_{1} \text { if } f_{i} \leq t \leq l_{i}
$$

where $c_{i}$ is the total number of credits earned, and thus $\frac{c_{i}}{\left(l_{i}-f_{i}+1\right)}$ is the average number of credits earned per quarter, during the period workers were in school and where $\psi_{0}$ and $\psi_{1}$ are additional regression parameters.

According to (3a), attending community college may be associated with lower earnings and the effect may increase with the number of credits taken. To the extent that school attendance truly causes earnings to decline, the parameters $\psi_{0}$ and $\psi_{1}$ are of significant policy importance as they would represent a large part of the costs associated with retraining that need to be balanced with its benefits.

It is possible, however, that in some cases, workers who earned more credits simply had difficulty finding a full-time job following their job loss and therefore elected to fill what would otherwise have been idle time by taking classes. In this case, the in-school effects on earnings is at least partially attributable to the lack of success of displaced workers' job searches rather than a true cost of school attendance. Such an interpretation may have most relevance in the quarter or two immediately after job loss when lack of luck in job search may plausibly explain unemployment or underemployment. By contrast, it seems likely that by the time workers have spent several quarters in school, they could have found a full time job, but instead chose to forego some earnings in the expectation of increased future wages.

Our primary interest is in the effects of schooling in the period after it is complete. In this case, we have found it important to allow for a transition period after workers leave school. That is, immediately after leaving community college classes, worker's earnings tend to be lower than they eventually become in the long-term. Indeed, immediately after leaving school we almost always have found that workers appear to have been worse off than they would have been without obtaining additional retraining. However, earnings tend to rise quickly in the year following the end of 
training, before leveling out to a new, higher level. This finding underscores the importance of having access to data for a long follow-up period when evaluating education and training programs for adults. Without the ability to observe at least some individuals for several quarters after leaving school, it would be very difficult to gauge the value of training.

To capture this temporal pattern in schooling effects, we specify the post-schooling effects as

$$
\tau_{i t}\left(c_{i}, f_{i}, l_{i}, z_{i}\right)=\tau_{0}+c_{i} \tau_{1}+\left(\frac{1}{t-l_{i}}\right) \tau_{2}+c_{i}\left(\frac{1}{t-l_{i}}\right) \tau_{3}, t>l_{i}
$$

In (3b), the parameters $\tau_{0}$ and $\tau_{2}$ capture discrete earnings differences between displaced workers who complete at least one community college credit and their counterparts who either do not enroll or enroll but do not complete any courses, as in the program-evaluation approach. The parameters $\tau_{1}$ and $\tau_{3}$ capture the effects of schooling that are proportional to the number of credits earned, as in the returns-to-education approach.

The long-run effects of community college attendance are given by the parameters $\tau_{0}$ and $\tau_{1}$ in (3b). The term $\left(\frac{1}{t-l_{i}}\right)$, which is equal to one in the period immediately after schooling, converges to zero with the passage of time. Thus, $\tau_{2}$ and $\tau_{3}$ capture short-run deviations from these longrun impacts. In particular, the discrete impact of community college attendance is $\tau_{0}+\tau_{2}$ in the period just after training, while the long-run effect is simply $\tau_{0}$. Similarly, the per-credit impact of community college schooling is $\tau_{1}+\tau_{3}$ in the period just after training, while the long-run effect is simply $\tau_{1}$. This specification allows for the possibility that the impact of community college credits on earnings is small or negative during the first few quarters after leaving school, but may grow (or decline) over time before leveling off in the long-term.

As noted, (3a) and (3b) allow for a discrete jump in earnings between zero and positive credits. However, the impact of additional credits is assumed constant. To test the robustness of our results to the latter assumption, we estimate models in which earnings are a step function of credits with several possible steps. This fits into the above framework if $c_{i}$ is reinterpreted to be a vector of indicator variables for worker $i$ earning credits in various ranges and the $\tau_{k}$ parameters in (3a) and (3b) are conformable vectors. 
Finally, our analysis of the data revealed that it is important to allow the effects of Group 1 and Group 2 courses to differ. In this case, $c_{i}$ is a vector whose components are the number of each type of credits earned and the $\tau_{k}$ parameters in (3a) and (3b) are conformable vectors.

While somewhat complicated, the model consisting of (1) - (3) is simply a large linear regression model. We estimate it by ordinary least squares using somewhat over 3.2 million worker-quarter observations on between 160 and 300 time varying independent variables plus 97,000 worker fixed effects and, in some cases, worker-specific time trends. This is accomplished using the usual Frisch-Waugh two step approach to eliminate worker-specific intercepts and/or trends. That is, writing the model as $y_{i t}=\alpha_{i}+\omega_{i} t+w_{i t} \lambda+\varepsilon_{i t}$ where $w_{i t}$ includes all the terms whose coefficients are not worker-specific, we estimate $\tilde{y}_{i t}=\tilde{w}_{i t} \lambda+\varepsilon_{i t}$, where $\tilde{y}_{i t}$ and $\tilde{w}_{i t}$ are deviations from worker-specific means in the case the case of simple worker-specific fixed effects $\left(\omega_{i}\right.$ are all zero) and deviations from worker-specific linear time trends in the case in which worker-specific time trends are also present. ${ }^{5}$ Stacking all the observations for worker $i$ to form $\tilde{y}_{i}$ and $\tilde{w}_{i}$, the estimator can be written as $\lambda=\left(\sum \tilde{w}_{i} \tilde{w}_{i}\right)^{-1} \sum \tilde{w}_{i} \tilde{y}_{i}$. Letting $e_{i}=\tilde{y}_{i}-\tilde{w}_{i} \lambda$ be the vector of residuals, we report standard errors based on $\operatorname{Cov}(\lambda)=\left(\sum \tilde{w}_{i}{ }^{\prime} \tilde{w}_{i}\right)^{-1}\left(\sum \tilde{w}_{i} e_{i} e_{i}{ }^{\prime} \tilde{w}_{i}\right)\left(\sum \tilde{w}_{i}{ }^{\prime} \tilde{w}_{i}\right)^{-1}$, the panel data analog of White's (1980) covariance matrix estimator, which is consistent in the presence of arbitrary forms of worker-specific heteroscedasticity and serial correlation.

\section{The Impact of Community College Schooling}

\section{Fixed Effects Estimates}

Table 2 reports estimates of the post-schooling training parameters from several variants of the fixed-effect version of our statistical model. In addition to the variables shown in the table, all

5. The computation of the deviations from worker-specific time trends is sped up considerably by noting that the deviation from trend of a variable that is a person-specific constant times a time varying variable is that same person-specific constant times the deviation from trend of the time varying variable. For instance, the deviation from individual specific trend of a variable such as $F_{i t}^{j} z_{i}$ is $\hat{F}_{i t}^{j} z_{i}$ where $\hat{F}_{i t}$ is the deviation from trend of $F_{i t}$. Thus the regression on time can be done just for the $F_{i t}^{j}$ variables and the result multiplied by the appropriate person-specific constants to get the full set of variables expressed as deviations from workerspecific time trends. 
models include the controls discussed in the previous section of the paper. ${ }^{6}$ The model shown in column (1) includes only post schooling dummies for males and females (the $\tau_{0}$ terms of model $(3 b)$ or $\left.\left(3 b^{\prime}\right)\right)$. The results indicate that during their post-schooling period, male workers who completed at least one credit earned on average about $\$ 140$ per quarter more than would otherwise have been expected on the basis of their other characteristics. The comparable figure for females is about $\$ 55$ per quarter. For men, such a figure represents about 3.3 percent of post-displacement earnings, while for women it is about 1.9 percent of post-displacement earnings. Given that workers complete about two thirds of a year of school on average, these earnings increases are lower than would be expected on the basis of standard estimates of the return to schooling.

As noted in the previous section, we find that the earnings of schooling participants are temporarily depressed in the quarters immediately after their training. Thus their average earnings over the relatively short follow-up period of our study may not reflect the average value of the training over the much longer horizon that is relevant for judging the value of the training. The model represented in the second column of Table 2 accounts for this phenomenon by adding the interaction between the post-schooling indicator and $\frac{1}{t-l_{i}}$. As discussed in the previous section, the coefficient on the post-schooling dummy, $\tau_{0}$, gives the estimate of the long-run effect and the sum of the coefficients on the post-schooling dummy and its interaction with $\left(\frac{1}{t-l_{i}}\right), \tau_{0}+\tau_{2}$, gives the effect in the quarter immediately after training.

In the case of males, we estimate the long-run effect of schooling is estimated to be about $\$ 385$ per quarter in the model of column (2). For females, the figure is about $\$ 220$. These figures represent about 9.3 percent of post-displacement earnings for men and about 7.6 percent for women. Given the number of credits completed by the typical participant, these estimates are in line with, or perhaps somewhat above, conventional estimates of the returns to schooling. The estimates in column (2) also indicate that immediately after training, earnings are substantially below their expected levels. In the case of men, the estimate is - \$453 (\$385 - \$839), while for women it is $\$ 334$. The estimates also indicate that the effect on earnings becomes positive in between two and three quarters after leaving school.

6. These include worker-specific and quarter-specific fixed effects, the age, gender, and minority status controls, the baseline and heterogeneous displacement terms, and separate dummies for male and female workers being in their schooling period and the interaction of these dummies with the number of courses taken in the quarter. 
The models shown in columns (1) and (2) use the traditional "program evaluation" approach that treats training as a binary event. In contrast, columns (3) and (4) are in the spirit of the "returns to schooling" literature by modeling the effect of training as being proportional to the amount of schooling. ${ }^{7}$ Column (3) simply includes the number of credits earned, $c_{i}$ interacted with the post schooling indicator. Column (4) also includes the interaction of the post schooling indicator with $\left(\frac{1}{t-l_{i}}\right)$. As with the first two columns, adding the adjustment variable, $\left(\frac{1}{t-l_{i}}\right)$, substantially raises the estimate of the long-run effect of schooling. With the adjustment term included, the long-run estimate of the impact of an additional community college credit is about $\$ 11$ per quarter for men and about $\$ 6.50$ per quarter for women. These numbers imply that a year of school (45 credits) would yield increases in earnings of about $\$ 485$ per quarter or 11.7 percent of post-displacement earnings for men and about $\$ 300$ per quarter or 10.4 percent of post-displacement earnings for women. Again, the estimates of the effects immediately after schooling ends are substantially negative, taking three quarters to turn positive.

Columns (5) and (6) of Table 2 show the results of including both terms that are binary and terms that are proportional to the number of credits. Focusing on the long-run effects shown in column (6), we see that a male worker would eventually expect his quarterly earnings to increase by about $\$ 285$ plus $\$ 5.50$ times the number of credits earned. The comparable figures for women are about $\$ 160$ per quarter and $\$ 3.75$ per credit per quarter. Taken at face value, the estimated intercept terms suggest quite large returns to "networking" or whatever other activities produce earnings gains associated with minimal accumulation of credits. The figures suggest that "just showing up" raises men's earnings by 6.8 percent and women's earnings by 5.5 percent. However, as was noted above, it seems possible that these estimates reflect, at least to some extent, the effects of selection of more able or more motivated people into training. That is, even after controlling for individual fixed effects and observable variation as described above, those workers who earn some positive number of credits may have been destined to have somewhat higher earnings even without receiving any training.

In light of these implausibly high estimates of the effects of "just showing up, we are inclined to

7. Of course, that literature usually works with the log of wage rates rather than the level of earnings as the dependent variable. We report results for log hourly wages below. Another difference between our results and the returns to schooling literature is that we controls for workers' age while the returns-to-schooling literature controls for workers' potential labor market experience. Replacing potential experience with age in the typical returns-to-schooling specification tends to reduce the estimates returns to schooling by a percentage point or two, an effect which should be kept in mind in comparing our results to those in the returns-toschooling literature. 
view the long-run per-credit impacts shown in column (6) as being the most likely to represent the true impact of training. The values of about $\$ 5.50$ per credit for men and of about $\$ 3.75$ per credit for women imply that the predicted effects of a year of schooling work out to about 6.0 percent of post-displacement earnings for men and 5.8 percent for women. The positive intercept terms estimated in column (6) and the lower values of the estimated impacts of a credit, suggest to us that the estimates obtained from column (4), which are in the spirit of "returns to schooling" studies like Kane and Rouse $(1993 ; 1995))$, overstate the true effects of community college schooling on earnings.

\section{Worker-specific Time Trend Estimates}

Table 3 has the same format as Table 2, but reports estimates from models that allow worker-specific time trends as well as fixed effects. The pattern of results across models is similar to that in Table 2. Models that allow for a transition process after workers leave school continue to indicate much larger long-run impacts of attendance and credits that those that do not. Moreover, there continues to be a positive earnings differential associated with minimal credit accumulation. Finally, the per-credit impacts from column (6), which allows for effects of just showing up, are smaller than those from column (4), which do not.

An important difference between Tables 2 and 3 is that the estimated per-credit impacts in the most general models (column (6) in the tables) are considerably larger when we include individual-specific time trends in model ( $3 \mathrm{~b})$. As shown in column 6 , the quarterly earnings gain for men is estimated to be $\$ 8.72$ per credit, while for women it is about $\$ 8.41$. These estimates imply that an academic year of credits increases men's earnings by 9.4 percent of post-displacement earnings, whereas the comparable figure for women is 13.1 percent. Both these figures are quite respectable by the standards of the returns-to-schooling literature.

The fact that estimated impacts increase with the inclusion of worker-specific time trends indicates that, controlling for observable factors including age, workers who earn more credits tend to have had earnings that were rising less rapidly than average in the period before they enrolled in community college courses. Thus the accumulation of credits seems, at least to some extent, to be a means of compensating for certain negative factors that effect those workers' earnings prospects. Once we allow for differences among workers in such earnings trends, our estimates of the per-credit impact of training increase.

\section{Nonlinear specifications}

The estimates in Tables 2 and 3 are based on model (3b), which assumes that the relationship 
between credits and earnings is linear. To explore how sensitive our results are to this assumption, we alternatively allow the relationship between credits and earnings to follow a step function. We consider the following categories of completed credits: 1 - 5 credits, 6 - 10 credits; 11 - 20 credits; 21 - 40 credits; 41 - 75 credits, and more than 75 credits, a level near that necessary to obtain an AA degree. There are approximately equal numbers of participants in each of these categories, except for the first category which contains more workers. This specification allows us to evaluate whether the relationship between credits and earnings is nonlinear, or even non-monotonic.

The results of the foregoing exercise are, with some exceptions, consistent with the estimates reported in Tables 2 and 3. The estimates based on the version of model (3) that includes worker specific time trends indicate that individuals who complete more credits have higher earnings. For males earnings rise sharply with completed credits until an individual has completed about 40 credits. After this point there appears to be little additional benefit of completing more schooling. For females, there appears to much more modest gains associated with completing up to 40 credits. But, by contrast to males, female participants appear to benefit substantially from completing enough credits to obtain a degree. As shown by column (3) of Table 4, women who completed more than 75 credits earned on average more than $\$ 700$ per quarter more than their counterparts who completed 41 - 75 credits.

By contrast to the worker-specific time trend estimates, the fixed effect estimates in Table 4 reveal significant departures from what is predicted by the affine specification in Table 2 . As shown by column (1) of the table, we estimate that the earnings of male participants increase with credits only up to the 41-75 credit level. Men who completed more than 75 credits are estimated to earn about $\$ 425$ per quarter less than observationally similar men who completed 41 to 75 credits. It seems implausible that completing additional credits could have this adverse of an impact on long-term earnings. Given that the worker-specific time trends estimates do not suggest any drop in earnings associated with additional credits, it is likely that the drop in the fixed effect estimates at high levels of credits are due to such workers having lower earnings trends, rather than to any true negative effects of acquiring of earning additional community college schooling.

\section{Estimates of effects by type of credit}

Table 5 shows separate estimates of the impacts of the two types of course credits discussed in section II. Fixed effects estimates are in the left two columns and individual trends estimates are in the right two columns.

We find that the estimated long-run impacts of the more technically-oriented Group 1 courses are 
much larger than the impacts of Group 2 courses. The fixed effect estimates suggest that each Group 1 credit increases quarterly earnings by $\$ 15.72$ for men and $\$ 17.13$ for women. This implies that a year of Group 1 credits would, in the long-run, raise male trainee earnings by 17.0 percent of their typical post-displacement level. For women, the long-run earnings increase associated with a year of Group 1 credits is 26.7 percent. The estimates of the long-run impact of Group 1 credits obtained from the model incorporating worker-specific time trends also are large and similar to the fixed effect estimates. These results indicate that the earnings gain associate with an academic year of Group 1 credits is 13.6 percent for men and 29.3 percent for women.

In contrast to the positive results for Group 1 credits, the results in Table 5 suggest that obtaining Group 2 credits does not raise earnings in a meaningful way. Indeed, the long-run fixed-effects estimates are negative for both men and women. Negative estimates should not be rejected out of hand. Work experience itself tends to raise earnings. Thus if attending a course imparts no useful skills and reduces workers' time in the labor market, one would expect it to have a negative impact on subsequent earnings. However, the fixed effect estimate of $-\$ 9.98$ per credit for men is probably too negative to be reasonable. It implies that obtaining a year of Group 2 credits lowers men's earnings by the equivalent of 10.7 percent of post-displacement earnings, a figure that would be much larger than the likely effect of the loss of a year of labor market experience.

In work not reported here in detail, we examined the characteristics of workers who earned large numbers of Group 2 credits, finding that such workers tended to have both lower earnings levels and lower earnings growth in the periods before they enrolled in school. These unfavorable trends in their earnings suggest that they would have had lower earnings had they not earned community college credits. The estimates obtained from the worker-specific time trends model control for such differences in earnings trends among workers. As shown in the last two columns of Table 5, they suggest that the impacts of Group 2 courses are positive, but relatively close to zero. These results seems more reasonable than the corresponding fixed effect estimates. Of course, they still suggest that completing Group 2 courses does not, on average, increase displaced workers' earnings as substantially as Group 1 courses. Indeed, given the estimated standard errors, we cannot reject the hypothesis that the true effect of Group 2 credits is zero.

As with Tables 2 and 3, the estimates in Table 5 are based on a specification that assumes a linear relationship between earnings and Group1 and Group 2 credits. To explore how sensitive our results are to this assumption, we again examined a more flexible specification. In this case, earnings depend on discrete levels of both Group 1 and Group 2 credits. To avoid extremely small cell sizes, we limited the categories of each type of credit to 0 credits, 1 -5 credits, 6 - 20 credits and 21 or more credits. Estimates of the long-run impacts of each discrete combination of Group 1 and 
Group 2 credits relative to the case of earning no credits of either kind are shown in Table 6. For each of the four blocks of the table, the number of Group 1 credits increases as one reads across rows and the number of Group 2 credits increases as one reads down columns of the table.

With a few exceptions, the results of Table 6 are consistent with the simpler specifications shown in Table 5. For both the fixed effect and worker-specific time trends models, there is almost always a pronounced increase in earnings as the number of Group 1 credits increases for a fixed number of Group 2 credits. One exception is the case of the worker-specific time trends estimates for males with 6 to 20 credits. In that case, the maximum earnings increase is when the number of Group 1 credits is between 1 and 5. Whether increasing numbers of Group 2 credits are associated with higher or lower earnings depends on the form of the controls for unobserved heterogeneity. As one reads down the columns of the fixed effect results, earnings tend to decrease, except in the case of women earning one to five Group 1 credits, for which the pattern is relatively flat. On the other hand, as one reads down the columns of the worker-specific time trends results, earnings tend to increase at least weakly. Both of these results are consistent with those in Table 5. Thus the additive linear specification appears to provide a reasonable description of the data.

\section{A Specification Test}

As a means of testing the specifications underlying the models shown in column (6) of Table 5, we added additional variables to (1) to (3) that allow for an effect of schooling on earnings in periods after workers are displaced, but before they actually start school. Such effects must be zero in reality. However, as shown by Table 7, our estimates suggest that workers who will eventually earn credits tend to have especially depressed earnings in the period before they start school.

In the case of the fixed effect specification, male workers who will eventually earn a positive number of credits have earnings in the period between job loss and the start of school that are lower by about $\$ 225$ plus $\$ 5$ for each Group 1 credit they will eventually earn plus $\$ 8$ for each Group 2 credit they will eventually earn. In the case of women, the negative association with preschooling period earnings is lower for minimal numbers of credits, but increases more sharply as the number of Group 1 and Group 2 credits increases. These results suggest that the fixed effects specification fails to account for all factors that determine earnings and community college participation. The results shown in Table 7 for the worker-specific time trends specification also reveal a negative association between pre-training earnings and community college attendance and course completions. However, the magnitudes of the coefficients are somewhat smaller, except in the case of the discrete effect of participation for males. 
The unobserved factors that cause workers who will eventually participate in community college retraining to have lower earnings in the period before that retraining are likely to be at least somewhat persistent. Thus, in the absence of retraining, such workers likely would have continued to have somewhat lower than expected earnings. This likely negative correlation between unobserved factors influencing post-training earnings and the extent of retraining participation implies that the departures from the model's assumptions exhibited in Table 7 likely cause some downward bias in the estimates of the effects of community college attendance and credits on postschool earnings.

\section{Effects of Training on Hours Worked and Wage Rates}

So far, we have examined the relationship between displaced workers' community college schooling and their earnings. This relationship depends on how schooling separately affects the probability of being employed, the number of hours worked among those who work, and the level of hourly wages. Although most of the program evaluation literature focuses on the impact of training on earnings, most of the literature on the returns to schooling focuses the impact of schooling on hourly or weekly wages. Thus, the results reported above are not completely comparable to those commonly reported in the returns to schooling literature. More importantly, evidence that community college schooling increases wages and not just hours or the probability of working would support the contention that these programs raise the productivity of displaced workers.

Washington State administrative records report both quarterly earnings and quarterly "hours paid" for most workers. Accordingly, it is possible to separately estimate the impacts of schooling on wages and hours worked. To do this we estimate a version of (3a) and (3b) in which the dependant variable is individuals' log hourly wage as well as one in which the dependant variable is log quarterly hours worked. In both cases the sample is limited to the quarters in which hours paid were positive.

We report the fixed effect estimates of the impact of community college schooling on log quarterly hours worked and log hourly wages in Table 8 and the corresponding worker-specific time trends estimates in Table 9. In each table, the last column reports estimates of the impact of community college schooling on log earnings during quarters in which individuals worked. These estimates differ from those reported earlier in Tables 5 and 6 because person-quarter observations with zero reported hours or earnings are excluded. ${ }^{8}$

8. In Washington State, employers are instructed to report "hours paid," but in some case they do not. 
As shown by Table 8, fixed effect estimates suggest that completing at least one community college credit is associated with increases in both log hours worked and log hourly wage rates. For males, completing minimal credits is associated with about a two and one half percent increase in quarterly hours worked and a three percent increase in average wage rates. For females, completing at least some community college schooling is associated with about a three percent increase in hours, but a less than one percent increase in wages. As explained above, these impacts could be the effects of improved job search through chances to "network" at community college, but we believe that a significant portion of the estimated effect may be due to complex forms of selection into community college programs following the loss of a job.

The fixed effect results in Table 8 indicate that for men, Group 1 community college credits raise both hours worked and wage rates, while for women, the effect is limited to higher wages rates. In particular, increasing the number of Group 1 credits by 45 , which corresponds to one academic year of schooling, raises male hours worked by about 6.5 percent $(0.00144 * 45)$ and their wage rates by about 5.6 percent. The same increase in credits increases female wage rates by about 10.5 percent, but has a negligible impact on their hours worked. These effects of Group 1 credits on wages are thus at least comparable to those typically obtained in the returns to schooling literature, and in the case of women somewhat higher.

As shown by in the bottom two rows of Table 8, fixed effects estimates suggest that for both men and women, completing Group 2 credits is associated with increased hours worked, but also with significantly lower hourly wages. An academic year of Group 2 credits raises quarterly hours among those who work by about 7.2 percent for men and 6.5 percent for women. By contrast, this much schooling is associated with a 5.9 percent decline in hourly wages for males and a 4.2 percent decline in hourly wages for females. As we discussed above, when reporting the results in Tables 5 and 6 , we think it likely that these wage estimates reflect specification error and not the true impact of Group 2 courses on worker productivity.

To address the foregoing specification problem, we also estimated the impact of community college schooling on hourly wages and hours worked controlling for worker-specific time trends. As shown by Table 9, the discrete effect of earning a positive number of credits on hours increases to 5.0 percent for men and 4.5 percent for women when we allow for the more general form of unobserved heterogeneity. By contrast, the estimate of the discrete effect of training participation on wages becomes negative for both groups. In the case of men, the discrete effect is -3.3 percent, while for women it is -3.5 percent.

The worker-specific time trend results in Table 9 suggest that increases in Group 1 credits lead to 
somewhat larger increases in hours worked than the corresponding results controlling only for worker-specific fixed effects. For men, the increase in hours worked associated with an academic year of Group 1 credits is 9.0 percent (, while for women it is 4.9 percent. The increase in wage rates associated with a year of Group 1 credits is somewhat smaller after controlling for workerspecific time trends, but remains quite significant at 4.7 percent for men and 9.9 percent for women.

Finally, the worker-specific time trend results in Table 9, suggest that Group 2 courses raise the hours worked of women, but not men, and lead to small, but statistically insignificant, decreases in wage rates for both sexes. The increase in hours worked associated with completing an academic year of such credits is over 8 percent for women. The predicted drop in wage rates is 2.6 percent for men and 1.6 percent for women. Neither of these latter two effects, nor the effect of Group 2 credits on hours worked for men is statistically significant.

The foregoing results indicate that while earning Group 1 credits increases workers' wage rates, it does not increase them by as much as it does their earnings. Indeed, for both men and women, only about a third of the increase in earnings is attributable to increases in wage rates. The larger impact on earnings comes from increases in the probability of working and from the greater hours worked when employed. This conforms to the findings of the relatively small number of evaluations which have provided evidence on both earnings and wage rate impacts of training programs (LaLonde, 1995).

\section{Conclusions}

The foregoing results have several implications for the methodology of evaluating the impact of retraining on mid-career workers' labor market outcomes. First, when follow up periods are relatively short, allowance needs to be made for a transition period following the end of schooling. Because it appears to take several quarters before something close to the full effects of education are felt, a simple average of the effects during a short follow up period will tend to underestimate the true, long-run effects of retraining. Our device of including an additional term that converges to zero as time since schooling increases substantially raises the long-run estimates of retraining impacts.

Second, we find that it is important to allow for a discrete effect of schooling that is associated with just "showing up" and earning at least one credit. Previous work by Kane and Rouse (1995) has assumed that the effect of schooling on workers' labor market outcomes is proportional to the 
number of credits they earn. However, when we relax that assumption in our models that combine features of the typical program-evaluation and returns-to-schooling specifications, we find both a highly significant discrete effect of training and a lower estimate of the effect of credits. The exception is our result for females in specifications that include worker-specific time trends.

There are at least two possible interpretations of our estimates of the discrete effect of training associated with just "showing up" and earning at least one credit. It is possible that even very limited participation in community college training may aid workers' job searches by expanding their networks of contacts. However, we are inclined to view the estimates of these effects, at least for males, as implausibly large. Thus it seems likely that much of the estimated discrete effect of training may be due to some form of non-random selection into community college participation. These discrete effects remain even after controlling for worker-specific fixed effects and, in the case of males, worker-specific time trends. Thus, if they are due to selection, it must be a relatively complex form of selection in which workers who have recently experienced some change in circumstances associated with increased earnings are more likely to enter training. But, such forms of selection do not necessarily undermine our findings. If, conditional on entering retraining, the number of credits earned by workers is not related to other factors that cause workers' earnings to deviate from trend, then our measures of the effects of credits are not biased by such forms of selection. By contrast, in the pure returns-to-schooling specification that omits the discrete impact of retraining, estimates of the impact of credits are upwardly biased.

Third, allowing for worker-specific time trends in addition to worker-specific fixed effects is necessary to adequately control for the effects of unobserved heterogeneity on earnings. Displaced workers who obtain community college credits, especially those that obtain large numbers of Group 2 credits, tend to have more slowly growing earnings even before entering retraining. Thus simple fixed effects estimates of the effects of credits are biased downwards. Adding worker-specific time trends removes this source of bias.

Unfortunately, while we have made significant methodological progress, our models for quantifying the effects of community college retraining on workers' earnings still appear to have some shortcomings. In particular, our specification test that finds "impacts" of training before it occurs suggest that our framework still fails to adequately account for all the factors that may simultaneously effect earnings and retraining decisions. In addition, we view the large estimated impacts of minimal numbers of credits for males as further evidence of model misspecification.

Though they must be qualified in light of the evidence of the misspecification just mentioned, we also believe we can draw some tentative substantive conclusions about the impacts of community 
college attendance on displaced workers' earnings. In our preferred specification, the equivalent of a year of community college credits is estimated to increase displaced workers' earnings by about 9 percent for men and 13 percent for women. This is quite reasonable return on investment, especially considering that earning a year of credits does not usually entail the loss of a full year of earnings.

Moreover, these estimates seem more likely to be biased downward than upward. First, the above figures assume the estimated discrete impact of attendance on earnings is entirely due to selection bias. But, there may be actual positive effects of "just showing up" in community college. As we have noted above, these effects could derive from, for example, more efficient job search due to an expanded network of contacts. Second, our specification test suggests that workers who choose to return to community college tend to have suffered larger than normal earnings declines in the period before they begin retraining. Moreover, among those who return, the pre-training drop in earnings is larger for those who subsequently earn more credits. Given that there is likely to be positive serial correlation in the unobservable factors responsible for such outcomes, those workers with larger pre-training drops in earnings would probably have continued to suffer larger than normal losses in the future had they not entered training. This suggests that our estimates of the effects of community college training on earnings are biased downward due to our inability to fully control for all the factors that effect the magnitude of earnings declines.

We also found that the effects of community college credits on earnings depend significantly on the nature of the courses taken. A year of credits in Group 1 courses, which consist of more technically oriented vocational and math and science courses, is estimated to increase earnings by 14 percent for men and 29 percent for women. We estimate that about one third of these increases are due to increased hourly wage rates, with the rest attributable to higher hours of work. In contrast, we estimate smaller effects of earning credits in Group 2 courses, which consist of less technically oriented vocational and humanities and social science courses. Point estimates in models with worker-specific time trends suggest that an academic year of Group 2 credits increases earnings by about four percent. Unfortunately, the standard errors associated with these estimates are large enough that we cannot be confident that such effects are nonzero.

Given our findings on community college schooling for displaced workers, we estimate that the social benefit to cost ratios associated with the mix of community college schooling completed by displaced workers in our sample to be roughly 1.07. However, this net benefit results because of the very large returns to Group 1 courses and because about one-half of the credits completed by the males and about one-third of the credits completed by the females in our sample were in these subject areas. Our analysis suggests that the internal rate of return to such courses is roughly 10 
percent for males and roughly 17 percent for females. Besides the direct costs of the schooling, these rates of return estimates also take into account (1) the welfare cost associated with taxes used to subsidized community college schooling and (2) estimates of the foregone earnings associated with completing such schooling. ${ }^{9}$ By contrast, for Group 2 courses we estimate the internal rates of return to be negative for both groups. These figures indicate that, on average, community college schooling is at least a marginally productive social investment for displaced workers studied in this sample. Whether it is socially productive more generally appears to depend a great deal on the type of schooling that displaced workers receive.

9. We estimate the social cost of an academic year of community schooling to be approximately $\$ 19,000$ for displaced males and $\$ 18,000$ for displaced females. See the Appendix for details on how we arrived at these estimates. 


\section{References}

Aaronson, Daniel and Daniel Sullivan (1998), "The decline of job security in the 1990s: Displacement, anxiety, and their effect on wage growth," Economic Perspectives, Federal Reserve Bank of Chicago, Vol. 22, No. 1, First quarter, pp. 17-43.

Ashenfelter, Orley (1978). "Estimating the Effect of Training Programs on Earnings," Review of Economics and Statistics 60 (February): 47-57.

Ashenfelter, Orley, and Card, David (1985). "Using the Longitudinal Structure of Earnings to Estimate the Effect of Training Programs." Review of Economics and Statistics 67 (November): 648-60.

Ashenfelter, Orley, and Robert LaLonde, (1997), "The Economics of Training" in Handbook of Human Resources, D. Lewin, D. Mitchell, and M. Zaidi, eds., JAI Press, 1997.

Angrist, Joshua, and Newey, Whitney (1991). "Over-Identification Tests in Earnings Functions With Fixed Effects," Journal of Business and Economic Statistics, 9(3): 317 - 323 (July).

Bednarzik, Robert; and Jacobson, Louis (1994). "Analysis of the Dislocated Workers' Educational Training Program (DWETP): A Locally Funded Voucher-Like Program in Pittsburgh, Pennsylvania," mimeograph, Westat Inc.

Bloom, Howard (1984), "Estimating the Effect of Job-training Programs, Using Longitudinal Data: Ashenfelter's Findings Reconsidered," Journal of Human Resources, 19(4): 544-56.

Bloom, Howard (1990), Back to Work: Targeting reemployment Services for Displaced Workers, Kalamazoo, Michigan: W.E. Upjohn Institute for Employment Research.

Browning, E., (1987). "On the Marginal Welfare Cost of Taxation," American Economic Review, 77(1): 11 - 23.

Corson, Walter; Decker, Paul; Gleason; and Nicholson, Walter (1993). International Trade and Worker Dislocation: Evaluation of the Trade Adjustment Assistance Program, Final Report DOL contract No: 99-9-0805-75-071-01, Princeton: Mathematica Policy Research Inc.

Fallick, Bruce (1996). "A Review of the Recent Empirical Literature on Displaced Workers," Industrial and Labor Relations Review, 50 (1): 5 - 16.

Farber, Henry (1993). "The Incidence and Costs of Job Loss: 1982 - 1991," Brookings Papers on Economic Activity: Microeconomics, 1993(1): 73 - 119.

Farber, Henry (1997). "The Changing Face of Job Loss in the United States, 1981-1995" Brookings Papers on Economic Activity: Microeconomics, 1997(1): 55-128.

Flaim and Seghal (1985). "Displaced Workers of 1979 - 83: How well Have They Fared?" Bulletin 2240, U.S. Department of Labor, Bureau of Labor Statistics.

Freeman, Richard B. (1974), "Occupational Training In Proprietary Schools and Technical Institutes," Review of Economics and Statistics, 63:310 - 318.

Grubb, Norton (1993). "The Long-Run Effects of Proprietary Schools on Wages and 
Earnings: Implications For Federal Policy," Education Evaluation and Policy Analysis, 15(1): 17 - 33 (Spring).

Heckman, James, and Robb, Richard (1985). "Alternative Methods for Evaluating the Impact of Interventions." In Longitudinal Analysis of the Labor Market Data, ed. J.J. Heckman and B. Singer. Cambridge: Cambridge University Press.

Heckman James J., and Hotz, V. Joseph (1989). "Choosing Among Alternative Nonexperimental Methods for Estimating the Impact of Social Programs: The Case of Manpower Training." Journal of the American Statistical Association 84 (December): 862-74.

Heckman, James, Robert LaLonde, and Jeffrey Smith, (1999) The Economics and Econometrics of Active Labor Market Policies," in The Handbook of Labor Economics, eds. Orley Ashenfelter and David Card, Amsterdam: North-Holland, 1999.

Jacobson, Louis S.; LaLonde, Robert J.; and Sullivan, Daniel G. (1993a). "Earnings Losses of Displaced Workers," American Economic Review, 83(4):685 - 709.

---- (1993b). The Costs of Worker Dislocation, Kalamazoo, Michigan: W.E. Upjohn Institute for Employment Research.

---- (1993c). "Earnings Losses of High-Seniority Displaced Workers," Economic Perspectives, Federal Reserve Bank of Chicago, Vol. 17, No. 6, November/December, pp. 2-20.

---- (1999). "Participation in Community College Schooling and Its Effects on Displaced Workers' Earnings and Employment Prospects: A Study of Displace Workers From Washington State," Final Report for U.S Department of Labor, Employment and Training Administration, \#K6307-7-00-80-30, (September).

--- (2002). "Measures of Program Performance and the Training Choices of Displaced Workers," Targeting Employment Services, Randall W. Ebberts, Christopher J. O'Leary, and Stephen A. Wadner eds., Kalamazoo, Michigan: W.E. Upjohn Institute for Employment Research.

Kane, Thomas; and Rouse, Cecila (1993). "Labor Market Returns to Two- and Four- year College," mimeograph, Princeton University.

Kane, Thomas; and Rouse, Cecila (1995). "Labor Market Returns to Two- and Four- year College," American Economic Review, 85(3, June).: 600 - 14.

Kane, Thomas; and Rouse, Cecila (1999). "The Community College: Educating Students at the Margin Between College and Work," Journal of Economic Perspectives, 13(1, Winter).: 63 84 .

Kletzer, Lori (1998). “Job Displacement,” Journal of Economic Perspectives, 12(1): 115 - 36.

Leigh, Duane E. (1990). Does Training Work for Displaced Workers: A Survey of Existing Evidence, Kalamazoo, Michigan: W.E. Upjohn Institute for Employment Research.

Ruhm, Christopher (1991). “Are Workers Permanently Scarred by Job Displacements?" American Economic Review, 81:1, 319-323. 
Saint-Paul Gilles (1994). "Out in the Cold," European Economic Perspectives, London: Centre for Economic Policy Research, 4: 5-6.

White, Halbert (1980). "A Heteroscedasticity-Consistent Covariance Matrix Estimator and a Direct Test for Heteroscedasticity," Econometrica 48:817-38. 


\section{Appendix}

Notes on Displaced Workers, Administrative Earnings and Community College Records

There is no consensus as to the definition of a displaced worker. However, there are three common elements in most descriptions of such individuals:

(i) Displaced workers have not been discharged for cause;

(ii) Displaced workers have permanently separated from their former employer or have only a very small likelihood of being recalled to their old jobs;

(iii) Displaced workers have had strong prior attachment to the industry of their pre-displacement employer.

As a result of the foregoing description, studies of the consequences of job loss and of programs and policies to aid the victims of displacement have sought to limit their attention to unemployed workers with some or all of these characteristics. Recognition that job loss is potentially more costly for high-tenured workers has lead to U.S. Department of Labor in some of its publications to define displaced workers as persons having at least 3 or more years of tenure when they permanently lost their jobs (Flaim and Seghal, 1985).

Our Washington State sample is constructed from a data base on every individual who lost a job in that state between 1990.II and 1994.IV, who filed a valid claim to receive unemployment insurance benefits and who had accumulated at least six quarters of job tenure with his employer. From the state, we received two types of administrative records. First, we received quarterly earnings and unemployment insurance benefits administrative records that started in 1987 and continued through 1995. Second, we received machine-readable transcripts for all of these individuals who had enrolled in one of the state's 25 community colleges. These records cover the period starting with the fall term of 1989 and continuing through the end of 1995.

We excluded from our sample individuals who transferred to a four-year college or who acquired more than 135 community college credits. We also excluded workers whom the transcript records revealed were in school at the beginning of those records because of the possibility that they were actually in school in earlier quarters as well.

We restricted our sample of displaced workers in several ways in order to focus on individuals for whom the effects of retraining would likely be of the greatest policy interest. First, we limited our 
analysis to adults between the ages of 22 - 60 years old. We make the former age restriction because of the traditional policy interest in the displaced as a group of experienced workers who require retraining assistance and also because studies of the economically disadvantaged population suggest that youths respond differently to retraining services than do adults (Heckman, LaLonde, and Smith, 1999). We impose the latter age restriction because there is less policy interest in training workers close to retirement age.

Another restriction that we impose on our sample is that workers must have accumulated at least 12 quarters of service with their pre-displacement employers. We exclude workers with fewer quarters of tenure with their former employer because such individuals do not fall within common definitions of a displaced worker. In addition, because a rationale for subsidizing displaced workers' retraining is that the earnings losses associated with their displacements may be substantial, we chose not to analyze a group for whom on both theoretical and empirical grounds the adverse impacts of job loss are likely to be small.

We also limited our sample to displaced workers who remained "continuously attached" to the state's work force. We defined such a worker if he or she never had more than eight consecutive quarters without earnings, except during the period following his or her job loss and when he or she was enrolled in community college courses. This sample restriction ensures that each member of the sample was consistently attached to Washington State's employed work force throughout the sample period.

The Washington State sample used in our analysis contains more than 3 million person/quarter observations, on 97,262 individual workers. Of the latter number, 16,103 completed at least one credit in a Washington State community college.

\section{Computing the Benefits and Costs of Community College Schooling}

In the text we report the social benefit-cost ratios and internal rates of return for community college schooling. In our computation of the social benefits we consider only gains in earnings. We analyzed the expected benefits for a representative participant who works for 25 years and acquired the average number of Group 1 and Group 2 credits as reported in Table 1B. The 25 years figure is a plausible, although probably upwardly biased, estimate of the remaining work life for the average participant in our sample. We took account of the transition period after leaving community college schooling. When computing the social benefit-cost ratios, we discounted future earnings gains at a rate of 4 percent. 
We arrived at our estimates of the social cost of community college schooling as follows: First, using Kane and Rouse (1999), we estimated the average cost of a year of community college schooling to be about $\$ 8,000$ per student. This amount reflects the cost of tuition and expenditures by public sector. Second, we estimated the welfare cost or deadweight loss associated with the taxes raised to subsidized community colleges to be about $\$ 3,000$ (Browning, 1987; Heckman, LaLonde, and Smith, 1999). This amount is about 50 percent of $4 / 5$ of $\$ 8,000$ or 50 percent of the amount of the direct community college costs paid for by the public sector. We assumed that none of the public sector expenditures were in the form of stipends that covered participants' living expenses.

Finally, we used the estimated parameters of (3a) in the text to estimate the foregone earnings associated with acquiring community college schooling. These estimates were about $\$ 8,000$ per academic year for males and about $\$ 7,000$ per academic year for females. The estimates from our model did not suggest large differences between the average foregone earnings of male and female community college participants. To the extent that our estimates of the foregone earnings associated with community college participation overstate lost earnings, the estimates of internal rates of return as well the social benefit-cost ratios given in the text will be too small. When computing the social benefit-cost ratios for the displaced workers in our sample, we took into account that the average participant completed about two-thirds of an academic year of schooling. 
Table A: Classifications of Washington State Community College Classes

Group1: Quantitative or Technically Oriented Vocational courses

Health related courses

Technical/professional courses

Technical trades

Science/math academic courses.

Group 2:Non-quantitative Courses

Sales/service courses

Vocational courses not in Group 1

Social Science/humanities courses

Health/PE/consumer-oriented courses

Basic skills education

Other courses. 
Table 1: Characteristics and Community College Credits of Displaced Workers

Panel A: Characteristics of Individuals in Sample of Washington State Displaced Workers

\author{
Males $\quad$ Females
}

Participants Comparisons Participants Comparisons

(1)

(2)

(3)

(4)

Mean age at separation

35.9

39.0

37.2

40.3

Aged 20 - 29 at separation

0.306

0.190

0.257

0.158

Aged 40 - 59 at separation

0.307

0.426

0.373

0.497

Minority

0.113

0.140

0.100

0.136

Less than H.S. degree

0.081

0.151

0.051

0.122

More than H.S. degree

0.491

0.374

0.511

0.399

Mean job tenure at separation (quarters)

Greater than 6 years tenure

18.8

18.8

19.1

19.4

0.195

0.201

0.231

0.241

Industry of former employer

Aerospace/Motor Vehicle

0.177

0.104

0.118

0.082

Other Manufacturing

0.288

0.232

0.149

0.142

Other Goods Producing

0.155

0.227

0.043

0.055

Non-Goods Producing

0.380

0.437

0.690

0.721

Region of state

Rural

0.367

0.337

0.504

0.539

0.140

0.123

$\$ 30,351$

0.321

0.311

Seattle-Tacoma MSA

Other MSA

Mean earnings in 4 quarters

prior to separation (1995\$)

Mean earnings 1994Q3

to1995Q3 (1995\$)

Number of Observations
$\$ 29,486$

$\$ 16,643$

8,041
0.546

0.569

0.133

0.120

Notes: Comparison groups are comprised of displaced workers who did not earn community collegecredits during or after Fall quarter 1989. Workers earning more than three academic years of credits are excluded from the samples. See appendix for details of how the sample was constructed from administrative records. N umbers are proportions of the group with the given characteristic unless noted. 
Table 1 (continued)

Panel B: Credits Completed by Displaced Workers Who Completed at Least One Credit

All Credits

$\begin{array}{llllllll}\text { Males } & 31.9 & 0.279 & 0.150 & 0.147 & 0.139 & 0.133 & 0.153 \\ \text { Females } & 28.9 & 0.323 & 0.153 & 0.153 & 0.125 & 0.126 & 0.136\end{array}$

\begin{tabular}{cccccc} 
& Mean & 0 & $1-5$ & $6-20$ & $20+$ \\
\cline { 2 - 6 } Group 1 Credits & & & & & \\
Males & 16.9 & 0.312 & 0.229 & 0.219 & 0.241 \\
Females & 9.6 & 0.420 & 0.247 & 0.194 & 0.140
\end{tabular}

Group 2 Credits

$\begin{array}{llllll}\text { Males } & 15.1 & 0.283 & 0.225 & 0.260 & 0.232 \\ \text { Females } & 19.3 & 0.164 & 0.266 & 0.275 & 0.295\end{array}$

Notes: The first column gives the average number of credits completed in Washington State community colleges during and after the Fall quarter of 1989 by displaced workers who completed at least one such credit. Subsequent columns give the proportion of such workers earning the indicated number of credits. Group 1 credits are from courses teaching more technical academic and vocational skills. Group 2 credits are from other courses. See Table A 1 for a more detailed description of courses and the appendix for details on the transcript data from Washington State's 25 community colleges. 
Table 2: Fixed Effects Estimates of Impact of Community College Credits on Displaced Workers' Earnings ${ }^{\text {a }}$

\begin{tabular}{|c|c|c|c|c|c|c|}
\hline Model & (1) & (2) & (3) & (4) & (5) & (6) \\
\hline \multicolumn{7}{|l|}{ Males } \\
\hline Post-College ${ }^{b}$ & $\begin{array}{l}137.25 \\
(45.62)\end{array}$ & $\begin{array}{l}385.37 \\
(57.42)\end{array}$ & & & $\begin{array}{l}199.10 \\
(56.22)\end{array}$ & $\begin{array}{c}285.24 \\
(71.15)\end{array}$ \\
\hline Post-College $* 1 / \mathrm{k}^{\mathrm{c}}$ & & $\begin{array}{r}-838.59 \\
(74.33)\end{array}$ & & & & $\begin{array}{r}-415.02 \\
(95.74)\end{array}$ \\
\hline Credits*Post-College & & & $\begin{array}{c}0.12 \\
(1.16)\end{array}$ & $\begin{array}{l}10.79 \\
(1.57)\end{array}$ & $\begin{array}{l}-3.17 \\
(1.43)\end{array}$ & $\begin{array}{c}5.48 \\
(1.95)\end{array}$ \\
\hline Credits*Post-College $* 1 / \mathrm{k}$ & & & & $\begin{array}{r}-27.25 \\
(1.79)\end{array}$ & & $\begin{array}{r}-19.31 \\
(2.34)\end{array}$ \\
\hline
\end{tabular}

Females

\begin{tabular}{|c|c|c|c|c|c|c|}
\hline Post-College & $\begin{array}{c}54.97 \\
(35.11)\end{array}$ & $\begin{array}{l}219.75 \\
(43.62)\end{array}$ & & & $\begin{array}{l}102.42 \\
(20.24)\end{array}$ & $\begin{array}{l}157.87 \\
(51.65)\end{array}$ \\
\hline Post-College $* 1 / \mathrm{k}$ & & $\begin{array}{r}-553.53 \\
(56.91)\end{array}$ & & & & $\begin{array}{r}-254.39 \\
(71.20)\end{array}$ \\
\hline Credits*Post-College & & & $\begin{array}{l}-1.04 \\
(1.08)\end{array}$ & $\begin{array}{c}6.66 \\
(1.43)\end{array}$ & $\begin{array}{l}-2.76 \\
(1.26)\end{array}$ & $\begin{array}{c}3.69 \\
(1.69)\end{array}$ \\
\hline Credits*Post-College $* 1 / \mathrm{k}$ & & & & $\begin{array}{r}-20.04 \\
(1.59)\end{array}$ & & $\begin{array}{r}-15.07 \\
(2.00)\end{array}$ \\
\hline
\end{tabular}

a. The dependent variable is quarterly earnings. All models include demographic, heterogeneous displacement, and in-school controls as well as worker-specific fixed effects and period fixed effects. See section III of the text for detailed discussion of the specification. Robust standard errors are in parentheses.

b. Indicator variable equal to one during quarters after training participant left school.

c. $1 / \mathrm{k}$ denotes the reciprocal of the number of quarters after worker left school. 
Table 3: Worker-Specific Time Trends Estimates of Impact of Community College Credits on Displaced Workers' Earnings ${ }^{\text {a }}$

Model

Males

Post-College ${ }^{b}$

Post-College $* 1 / \mathrm{k}^{\mathrm{c}}$

Credits*Post-College

Credits*Post-College $* 1 / \mathrm{k}$

Females

Post-College

Post-College $* 1 / \mathrm{k}$

Credits*Post-College

Credits*Post-College $* 1 / \mathrm{k}$
(1)

(2)

(3)

(4)

(5)

(6)

$\begin{array}{ccccc}80.61 & 503.25 & & 118.68 & 322.13 \\ (51.74) & (71.12) & & (61.26) & (85.80) \\ & -816.30 & & & -423.75 \\ (70.74) & & & (91.22) \\ & & & & 8.72 \\ & (1.24) & (1.77) & (1.47) & (2.15) \\ & & & & -17.83 \\ & & -25.00 & & (2.22)\end{array}$

$\begin{array}{lc}-27.13 & 199.24 \\ (40.98) & (56.24) \\ & -435.06 \\ & (55.10)\end{array}$

$-12.63$

45.88

(47.04) (66.12)

35.06

$-120.71$

(69.53)

$\begin{array}{cccc}-1.04 & 9.20 & -0.84 & 8.41 \\ (1.15) & (1.74) & (1.32) & (2.05) \\ & & & \\ & -18.30 & & -16.17 \\ & (1.61) & & (2.04)\end{array}$

a. The dependent variable is quarterly earnings. All models include demographic, heterogeneous displacement, and in-school controls as well as worker-specific fixed effects and time trends and period fixed effects. See section III of the text for detailed discussion of the specification. Robust standard errors are in parentheses.

b. Indicator variable equal to one during quarters after training participant left school.

c. $1 / \mathrm{k}$ denotes the reciprocal of the number of quarters after worker left school. 
Table 4: Estimates of Nonlinear Impact of Community College Credits on Earnings ${ }^{\mathrm{a}}$

\begin{tabular}{lcccc} 
& \multicolumn{2}{c}{ Fixed Effects } & \multicolumn{2}{c}{$\begin{array}{c}\text { Worker-Specific Time } \\
\text { Trends }\end{array}$} \\
& $\begin{array}{c}\text { Long-Run } \\
\text { Impact }\end{array}$ & $\begin{array}{c}\text { Transition } \\
\text { Effect }^{c}\end{array}$ & $\begin{array}{c}\text { Long-Run } \\
\text { Impact }^{b}\end{array}$ & $\begin{array}{c}\text { Transition } \\
\text { Effect }^{c}\end{array}$ \\
\hline Males & & & & \\
1 to 5 credits & 102.98 & -256.69 & 135.00 & -205.48 \\
& $(94.60)$ & $(132.49)$ & $(114.30)$ & $(128.12)$ \\
6 to 10 credits & 385.42 & -657.81 & 398.45 & -645.73 \\
& $(122.69)$ & $(170.06)$ & $(150.28)$ & $(165.31)$ \\
11 to 20 credits & 572.66 & -1000.76 & 743.20 & -991.95 \\
& $(132.06)$ & $(175.00)$ & $(158.21)$ & $(168.58)$ \\
21 to 40 credits & 794.20 & -1354.89 & 989.38 & -1378.02 \\
& $(134.28)$ & $(175.62)$ & $(167.24)$ & $(171.17)$ \\
41 to 75 credits & 810.80 & -1663.15 & 780.71 & -1422.49 \\
& $(166.26)$ & $(207.74)$ & $(194.73)$ & $(213.35)$ \\
greater than 75 credits & 387.73 & -1878.46 & 992.44 & -2000.42 \\
& $(200.26)$ & $(223.05)$ & $(214.75)$ & $(212.14)$
\end{tabular}

Females

1 to 5 credits

$\begin{array}{lccc}122.52 & -200.26 & 68.48 & -127.58 \\ (61.81) & (89.99) & (80.33) & (89.14)\end{array}$

6 to 10 credits

169.88

$-299.09$

104.49

$-180.84$

(90.47)

(134.82)

(116.08)

(132.62)

11 to 20 credits

456.15

$-806.11$

341.82

$-476.54$

(119.44)

(148.82)

(137.68)

(141.53)

21 to 40 credits

216.56

$-815.59$

127.71

$-747.27$

(118.82)

(150.51)

(144.88)

(147.73)

41 to 75 credits

$$
309.41
$$

$-1149.22$

311.49

$-937.86$

(151.84)

(167.93)

(187.00)

(172.68)

greater than 75 credits

$\begin{array}{lr}543.26 & -1655.98 \\ (178.61) & (204.00)\end{array}$

1049.51

$-1730.48$

(203.61)

(204.75)

a. The dependent variable is quarterly earnings. All models include demographic, heterogeneous displacement, and in-school controls as well as individual and period fixed effects. The models shown in columns 3 and 4 also include worker-specific time trends. See section III of the text for detailed discussion of the specification. Robust standard errors are in parentheses.

b. Coefficient of indicator variable equal to one during quarters after training participant left school and credits in range indicated.

c. Coefficient of indicator variable equal to one during quarters after training participant left school and credits in range indicated times reciprocal of number of quarters after schooling. 
Table 5: Estimates of Impact of Group 1 and Group 2 Community College Credits on Earnings $^{\mathrm{a}}$

\begin{tabular}{lcccc} 
& \multicolumn{2}{c}{ Fixed Effects } & \multicolumn{2}{c}{ Torker-Specific Time } \\
& Males & Females & Males & Females \\
& 317.81 & 171.79 & 329.17 & 58.04 \\
& $(71.48)$ & $(51.56)$ & $(86.54)$ & $(65.88)$ \\
Post-College ${ }^{\mathrm{b}}$ & -407.96 & -255.53 & -410.05 & -120.66 \\
Post-College * $1 / \mathrm{k}^{\mathrm{c}}$ & $(96.44)$ & $(71.29)$ & $(92.20)$ & $(69.49)$ \\
& 15.72 & 17.13 & 12.61 & 18.69 \\
Group 1 Credits*Post-College & $(2.59)$ & $(3.71)$ & $(2.92)$ & $(5.04)$ \\
& -20.90 & -19.48 & -15.63 & -16.90 \\
Group 1 Credits*Post-College * 1/k & $(3.07)$ & $(4.06)$ & $(2.88)$ & $(4.65)$ \\
& -9.98 & -4.31 & 3.68 & 2.36 \\
Group 2 Credits*Post-College & $(3.17)$ & $(2.29)$ & $(3.73)$ & $(2.80)$ \\
& -16.66 & -12.34 & -21.49 & -15.69 \\
Group 2 Credits*Post-College * 1/k & $(3.93)$ & $(2.72)$ & $(3.88)$ & $(2.72)$
\end{tabular}

a. The dependent variable is quarterly earnings. All models include demographic, heterogeneous displacement, and in-school controls as well as individual and period fixed effects. The models shown in columns 3 and 4 also include worker-specific time trends. See section III of the text for detailed discussion of the specification. Robust standard errors are in parentheses.

b. Indicator variable equal to one during quarters after training participant left school.

c. $1 / \mathrm{k}$ denotes the reciprocal of the number of quarters after worker left school. 
Table 6: Estimates of Long-Run Nonlinear Impact of Group 1 and Group 2 Community College Credits on Earnings ${ }^{\text {a }}$

\begin{tabular}{|c|c|c|c|c|c|c|c|c|}
\hline \multirow[b]{3}{*}{ Group 2 credits } & \multicolumn{4}{|c|}{ Fixed Effects } & \multicolumn{4}{|c|}{ Worker-Specific Time Trends } \\
\hline & \multicolumn{4}{|c|}{ Group 1 credits } & \multicolumn{4}{|c|}{ Group 1 credits } \\
\hline & 0 & 1 to 5 & 6 to 20 & $20+$ & 0 & 1 to 5 & 6 to 20 & $20+$ \\
\hline \multicolumn{9}{|l|}{ Males } \\
\hline 0 & 0.00 & $\begin{array}{c}525.65 \\
(149.46)\end{array}$ & $\begin{array}{l}1052.37 \\
(144.95)\end{array}$ & $\begin{array}{l}1465.89 \\
(206.69)\end{array}$ & 0.00 & $\begin{array}{c}273.00 \\
(182.55)\end{array}$ & $\begin{array}{c}608.07 \\
(196.15)\end{array}$ & $\begin{array}{c}494.38 \\
(263.61)\end{array}$ \\
\hline 1 to 5 & $\begin{array}{l}-201.12 \\
(120.37)\end{array}$ & $\begin{array}{c}25.66 \\
(306.30)\end{array}$ & $\begin{array}{c}906.78 \\
(334.01)\end{array}$ & $\begin{array}{c}990.31 \\
(327.41)\end{array}$ & $\begin{array}{c}22.64 \\
(146.55)\end{array}$ & $\begin{array}{c}539.07 \\
(319.50)\end{array}$ & $\begin{array}{c}903.83 \\
(360.29)\end{array}$ & $\begin{array}{l}1179.08 \\
(457.57)\end{array}$ \\
\hline 6 to 20 & $\begin{array}{l}-133.47 \\
(148.00)\end{array}$ & $\begin{array}{c}550.75 \\
(246.98)\end{array}$ & $\begin{array}{c}824.24 \\
(290.03)\end{array}$ & $\begin{array}{c}606.29 \\
(293.11)\end{array}$ & $\begin{array}{c}-17.74 \\
(175.00)\end{array}$ & $\begin{array}{l}1781.12 \\
(270.58)\end{array}$ & $\begin{array}{c}1345.64 \\
(324.50)\end{array}$ & $\begin{array}{l}1042.49 \\
(311.20)\end{array}$ \\
\hline $20+$ & $\begin{array}{c}380.94 \\
(225.11)\end{array}$ & $\begin{array}{c}237.91 \\
(240.92)\end{array}$ & $\begin{array}{c}201.54 \\
(277.11)\end{array}$ & $\begin{array}{c}418.97 \\
(259.37)\end{array}$ & $\begin{array}{c}428.11 \\
(266.28)\end{array}$ & $\begin{array}{c}714.71 \\
(291.98)\end{array}$ & $\begin{array}{c}1309.55 \\
(314.32)\end{array}$ & $\begin{array}{l}1372.06 \\
(269.62)\end{array}$ \\
\hline \multicolumn{9}{|l|}{ Females } \\
\hline 0 & 0.0 & $\begin{array}{c}212.81 \\
(109.54)\end{array}$ & $\begin{array}{c}847.98 \\
(192.59)\end{array}$ & $\begin{array}{c}963.58 \\
(403.88)\end{array}$ & 0.0 & $\begin{array}{c}145.91 \\
(141.41)\end{array}$ & $\begin{array}{c}471.85 \\
(233.00)\end{array}$ & $\begin{array}{c}471.90 \\
(659.99)\end{array}$ \\
\hline 1 to 5 & $\begin{array}{c}48.42 \\
(74.72)\end{array}$ & $\begin{array}{c}315.04 \\
(196.11)\end{array}$ & $\begin{array}{c}577.29 \\
(299.91)\end{array}$ & $\begin{array}{c}758.39 \\
(509.57)\end{array}$ & $\begin{array}{l}-11.16 \\
(99.45)\end{array}$ & $\begin{array}{c}230.34 \\
(225.30)\end{array}$ & $\begin{array}{c}619.24 \\
(333.61)\end{array}$ & $\begin{array}{c}643.51 \\
(479.39)\end{array}$ \\
\hline 6 to 20 & $\begin{array}{l}108.74 \\
(94.98)\end{array}$ & $\begin{array}{c}510.37 \\
(195.38)\end{array}$ & $\begin{array}{c}222.08 \\
(217.70)\end{array}$ & $\begin{array}{l}1027.55 \\
(327.37)\end{array}$ & $\begin{array}{c}100.12 \\
(118.18)\end{array}$ & $\begin{array}{c}422.33 \\
(223.27)\end{array}$ & $\begin{array}{c}181.37 \\
(281.74)\end{array}$ & $\begin{array}{c}514.22 \\
(351.89)\end{array}$ \\
\hline $20+$ & $\begin{array}{l}-172.38 \\
(202.23)\end{array}$ & $\begin{array}{c}376.22 \\
(192.78)\end{array}$ & $\begin{array}{c}158.46 \\
(158.51)\end{array}$ & $\begin{array}{c}337.61 \\
(212.52)\end{array}$ & $\begin{array}{c}84.39 \\
(239.92)\end{array}$ & $\begin{array}{c}435.89 \\
(267.81)\end{array}$ & $\begin{array}{c}268.69 \\
(183.97)\end{array}$ & $\begin{array}{c}971.36 \\
(243.51)\end{array}$ \\
\hline
\end{tabular}

a. The dependent variable is quarterly earnings. All models include demographic, heterogeneous displacement, and in-school controls as well as individual and period fixed effects. The models shown in columns 5 through 8 also include worker-specific time trends. Table entries are coefficients of indicator variables equal to one during quarters after training participant left school and Group 1 and Group2 credits in ranges indicated. Models also include interactions of these indicator variables with the reciprocal of the number of quarters after workers left school. See section III of the text for detailed discussion of the specification. Robust standard errors are in parentheses. 
Table 7: Estimates of Impact of Group 1 and Group 2 Community College Credits on Earnings Prior To Community College Attendance ${ }^{\mathrm{a}}$

\begin{tabular}{lcccc} 
& \multicolumn{2}{c}{ Fixed Effects } & \multicolumn{2}{c}{$\begin{array}{c}\text { Torker-Specific Time } \\
\text { Trends }\end{array}$} \\
& Males & Females & Males & Females \\
\hline Pre-College $^{\mathrm{b}}$ & -226.52 & -132.94 & -259.62 & -116.75 \\
& $(99.32)$ & $(68.12)$ & $(88.68)$ & $(63.19)$ \\
Group 1 Credits*Pre-College & -5.09 & -10.22 & -3.85 & -7.38 \\
& $(2.66)$ & $(3.26)$ & $(2.46)$ & $(2.79)$ \\
Group 2 Credits*Pre-College & -8.05 & -8.56 & -4.31 & -6.75 \\
& $(2.72)$ & $(1.97)$ & $(2.43)$ & $(1.76)$
\end{tabular}

a. The dependent variable is quarterly earnings. All models include demographic, heterogeneous displacement, and in-school controls as well as individual and period fixed effects. The models shown in columns 3 and 4 also include worker-specific time trends. See section III of the text for detailed discussion of the specification. Robust standard errors are in parentheses.

b. Indicator variable equal to one during quarters after training participant was displaced and before training participant earned first community college credit. 
Table 8: Fixed Effect Estimates of Impact of Group 1 and Group 2 Community College Credits on Hours Worked, Average Wage Rate, and Earnings ${ }^{\mathrm{a}}$

\begin{tabular}{lcccccc} 
& \multicolumn{2}{c}{ Log Hours } & \multicolumn{2}{c}{ Log Wage } & \multicolumn{2}{c}{ Log Earnings } \\
& Males & Females & Males & Females & Males & Females \\
\hline Post-College $^{\mathrm{b}}$ & 0.02568 & 0.03126 & 0.03003 & 0.00714 & 0.05570 & 0.03840 \\
& $(0.01087)$ & $(0.01150)$ & $(0.00807)$ & $(0.00716)$ & $(0.01261)$ & $(0.01328)$ \\
Post-College * $1 / \mathrm{k}^{\mathrm{c}}$ & -0.03723 & -0.06006 & -0.03088 & -0.01933 & -0.06811 & -0.07938 \\
& $(0.01765)$ & $(0.01816)$ & $(0.01142)$ & $(0.01031)$ & $(0.01892)$ & $(0.01959)$ \\
& 0.00144 & 0.00026 & 0.00124 & 0.00234 & 0.00268 & 0.00260 \\
Group 1 Credits*Post-College & $(0.00041)$ & $(0.00080)$ & $(0.00033)$ & $(0.00053)$ & $(0.00047)$ & $(0.00096)$ \\
& -0.00302 & -0.00250 & -0.00193 & -0.00214 & -0.00496 & -0.00464 \\
Group 1 Credits*Post-College * 1/k & $(0.00070)$ & $(0.00110)$ & $(0.00042)$ & $(0.00069)$ & $(0.00073)$ & $(0.00122)$ \\
& 0.00161 & 0.00144 & -0.00131 & -0.00094 & 0.00030 & 0.00051 \\
Group 2 Credits*Post-College & $(0.00061)$ & $(0.00060)$ & $(0.00041)$ & $(0.00035)$ & $(0.00072)$ & $(0.00067)$ \\
& -0.00528 & -0.00315 & -0.00175 & -0.00118 & -0.00703 & -0.00433 \\
Group 2 Credits*Post-College * 1/k & $(0.00100)$ & $(0.00090)$ & $(0.00054)$ & $(0.00047)$ & $(0.00110)$ & $(0.00094)$
\end{tabular}

a. Dependent variables are log quarterly hours, log average wage rate, and log earnings. All models include demographic, heterogeneous displacement, and in-school controls as well as individual and period fixed effects. Samples are limited to those worker-quarters for which the logarithms are defined. One academic year of community college schooling equals 45 credits. See section III of the text for detailed discussion of the specification. Robust standard errors are in parentheses.

b. Indicator variable equal to one during quarters after training participant left school.

c. $1 / \mathrm{k}$ denotes the reciprocal of the number of quarters after worker left school. 
Table 9: Worker-Specific Time Trends Estimates of Impact of Group 1 and Group 2 Community College Credits on Hours Worked, Average Wage Rate, and Earnings ${ }^{\text {a }}$

\begin{tabular}{lccccccc} 
& \multicolumn{2}{c}{ Log Hours } & \multicolumn{2}{c}{ Log Wage } & \multicolumn{2}{c}{ Log Earnings } \\
& Males & Females & Males & Females & Males & Females \\
\hline Post-College $^{\mathrm{b}}$ & 0.05034 & 0.04538 & -0.03283 & -0.03502 & 0.01751 & 0.01036 \\
& $(0.01620)$ & $(0.01698)$ & $(0.01041)$ & $(0.00990)$ & $(0.01726)$ & $(0.01805)$ \\
Post-College * $1 / \mathrm{k}^{\mathrm{c}}$ & -0.05571 & -0.06808 & 0.01834 & 0.01299 & -0.03737 & -0.05509 \\
& $(0.01970)$ & $(0.01970)$ & $(0.01185)$ & $(0.01091)$ & $(0.02039)$ & $(0.02041)$ \\
& 0.00201 & 0.00108 & 0.00104 & 0.00220 & 0.00305 & 0.00328 \\
Group 1 Credits*Post-College & $(0.00071)$ & $(0.00132)$ & $(0.00041)$ & $(0.00078)$ & $(0.00073)$ & $(0.00146)$ \\
& -0.00257 & -0.00164 & -0.00183 & -0.00142 & -0.00440 & -0.00306 \\
Group 1 Credits*Post-College * 1/k & $(0.00080)$ & $(0.00143)$ & $(0.00044)$ & $(0.00078)$ & $(0.00080)$ & $(0.00153)$ \\
& 0.00001 & 0.00186 & -0.00058 & -0.00035 & -0.00056 & 0.00151 \\
Group 2 Credits*Post-College & $(0.00093)$ & $(0.00084)$ & $(0.00050)$ & $(0.00048)$ & $(0.00096)$ & $(0.00087)$ \\
& -0.00311 & -0.00286 & -0.00204 & -0.00144 & -0.00516 & -0.00430 \\
Group 2 Credits*Post-College * 1/k & $(0.00113)$ & $(0.00099)$ & $(0.00053)$ & $(0.00051)$ & $(0.00119)$ & $(0.00101)$
\end{tabular}

a. Dependent variables are log quarterly hours, log average wage rate, and log earnings. All models include demographic, heterogeneous displacement, and in-school controls as well as worker-specific fixed effects and time trends and period fixed effects. Samples are limited to those worker-quarters for which the logarithms are defined. One academic year of community college schooling equals 45 credits. See section III of the text for detailed discussion of the specification. Robust standard errors are in parentheses.

b. Indicator variable equal to one during quarters after training participant left school.

c. $1 / \mathrm{k}$ denotes the reciprocal of the number of quarters after worker left school. 
Figure 1: Earnings of Trainees and Comparisons Workers Dlsplaced In 1991

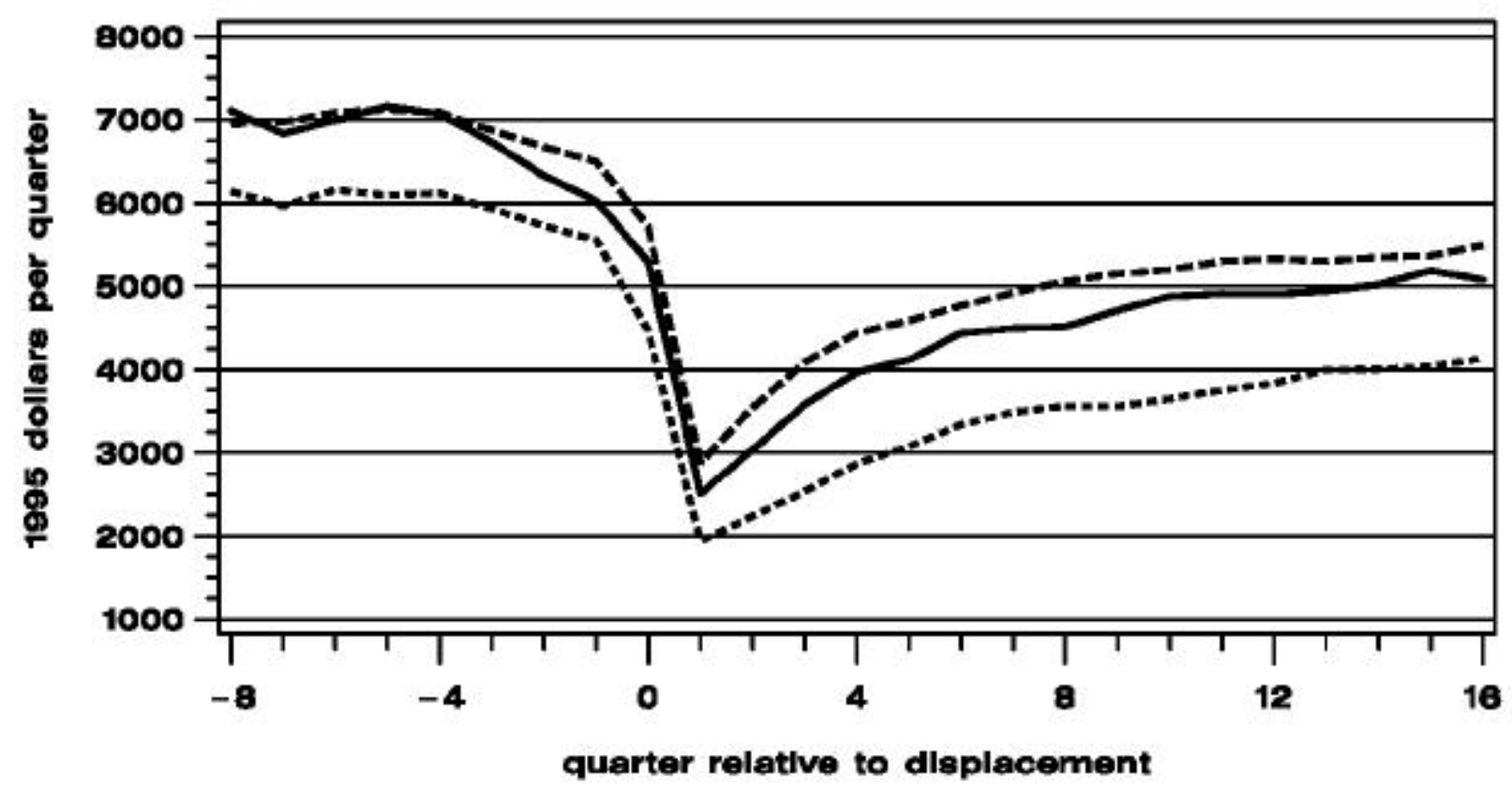

PLOT 
